\title{
Estimating crystallization pressure of peraluminous melts: An \\ Experimentally-based empirical approach
}

LEI YANG ${ }^{1 *}$, GUILHERME A. R. GUALDA ${ }^{2}$,

CALVIN F. MILLER ${ }^{2}$, FU-YUAN Wu ${ }^{1}$

${ }^{1}$ Institute of Geology and Geophysics, CAS, Beijing 100029, China (*correspondence: yanglei415@mails.ucas.ac.cn) ${ }^{2}$ Department of Earth and Environmental Sciences,

Vanderbilt University, Nashville, Tennessee 37240, USA

From the phase relations in the haplogranitic system, we know that the stability field of quartz increase while the stability field of feldspars decreases with increasing pressure [1]. However, multi-components added in melt will drive the compositions of the cotectic melt deviating from haplogranitic system. Relative to metaluminous granitic magma, excess aluminum in peraluminous system will drive the location of cotectic to quartz apex [2]. In this work, we present a series of calibrations to compiled experimental cotectic glass compositions [3] and regressed empirical function between corrected quartz content and pressure (Figure 1).
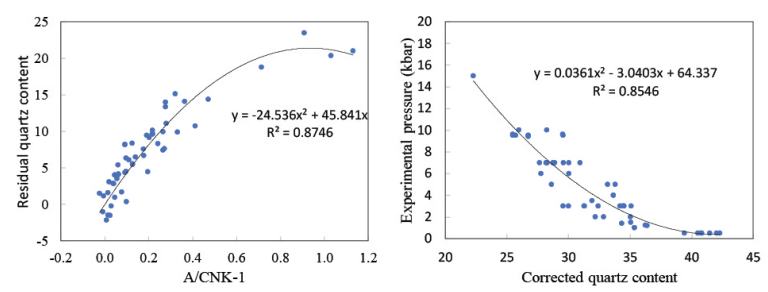

Figure 1 Peraluminous index $\left(\mathrm{A} / \mathrm{CNK}-1=\left[\mathrm{Al}_{2} \mathrm{O}_{3} /(\mathrm{CaO}+\right.\right.$ $\left.\left.\mathrm{Na}_{2} \mathrm{O}+\mathrm{K}_{2} \mathrm{O}\right)-1\right]$, in mole content) versus residual quartz content (left) and experimental pressure versus corrected quartz content (right). Residual quartz content was calculated by quartz content in peraluminous system minus in haplogranitic system.

The comparison with two natural examples of peraluminous rhyolite [4,5] shows that our approach is validity. However, it still is a roughly calibrating scheme, one sigma uncertainty is $1.4 \mathrm{kbar}$, it was given by standard error from regression.

[1] Tuttle \& Bowen (1958) Geol. Soc. Am. Mem. 74. [2] Holtz et al (1992) Eur. J. Mineral 4, 137-152. [3] Hirschmann et al (2008) Geochem. Geophys. Geosyst. 9, Q03011. [4] Audétat (2013) Chem. Geol. 360-361, 99-104. [5] Dailey et al (2018) American Mineralogist 103, 1228-1252. 